\title{
Pectinase: A Useful Tool in Fruit Processing Industries
}

\author{
Heena Verma ${ }^{1}$, Lokesh K Narnoliya ${ }^{2}$ and Jyoti Singh Jadaun ${ }^{3 *}$ \\ ${ }^{1}$ Department of Microbiology, Panjab university, India \\ ${ }^{2}$ Department of Biotechnology (DBT), Center of Innovative and Applied Bioprocessing (CIAB), India \\ ${ }^{3}$ Dyanand Girls Post Graduate College, India
}

Submission: February 03, 2018; Published: March 07, 2018

*Corresponding author: Jyoti Singh Jadaun, Dyanand Girls Post Graduate College, 13/394, Parwati Bagla Rd, Kanpur, Uttar Pradesh 208001, India, Email: jsjdgpg2017@gmail.com

\begin{abstract}
Owing to increase in the demand of fruit juices and fruit products, it became an indispensable need for the fruit processing industries to improve the quality of the fruit juices in a cost effective manner. Enzymes, being the highly efficient biocatalysts, are used at different steps in the process of juice production. Pectinases are used for the clarification of the juice by breaking the polysaccharide pectin structure present in the cell wall of plants into galacturonic acid monomers. Pectin structure breakage facilitates the filtration process and it increases the total yield of juice. Visual acceptance of the juice by the consumers need better clarity and improved colour that remain stable even during cold storage of the product.
\end{abstract}

Keywords: Biocatalyst; Pectinase; Amylase; Cellulase; Pectin; Starch; Galacturonic acid; Clarification; Juice extraction

Abbreviations: PG: Polygalcturonase; PE: Pectin Esterase; PL: Pectin Lyase; PMG: Polymethyl Galacturonases; GRAS: Generally Regarded as Safe; USFDA: United States Food and Drugs Administration

\section{Introduction}

Over the past decade, fruit and vegetable juice market has rapidly grown and is expected to grow more in near future due to the changing life style, more travelling, easy adaptation to the western culture and increase in the health awareness, [1]. Good quality juice production is impossible without the use of enzymes. There is a tremendous increase in utilization of food processing enzymes such as pectinase in juice industries. Pectinase is the enzyme which is in use since ancient time and its commercial applications were first observed in 1930 for the preparation of wines and fruit juices [2]. Generally, food and fruit processing industries use a variety of enzymes to enhance the quality of products as well as reducing the overall production cost [3]. Enzymes are biocatalysts that catalyze and accelerate various biological reactions [4]. Fruit Juice industries mainly involve juice clarification that is carried out by depectinization enzymes i.e. pectinase enzyme.

Pectin is an acidic heteropolysaccharide present in the middle lamella of plant cell wall [5]. Pectinases are used to breakdown this pectin polymer into monomer sugars i.e. galacturonic acid. Applications of pectinase enzyme are diverse with respect to its use in various industries. For examples pectinases are used in fruit juice industries for processing of fruits and vegetables to improve the quality of juice. In wine industry for maceration of the fruits tissue, as a macerating enzyme on vegetable to extract oil that is used for various purposes ranging from aromatic products to cosmetics and detergent industry as well. Pectinases are used in various food products to develop essential flavour. They are used in coffee as well as instant tea preparation to reduce viscosity and mucilage [6]. Alkaline pectinases are used in paper and pulp industry for the production of improved quality of paper without producing toxic effluent, and for the treatment of waste water from various industries that contain pectinacious waste $[1,6]$

\section{Structural and Functional Properties of Pectin}

Pectin is a negatively charged high molecular weight heteropolysaccharide that is composed of a main chain of $\alpha(1 \rightarrow 4)$ linked D-galacturonic acid monomers. It has rhamnose residues in the main chain and side chains are composed of arabinose, galactose and xylose. It is a naturally-occurring polysaccharide 
which provides strength and firmness to plant tissues. Pectin is consumed by humans as a natural diet in the form of fruits and vegetables though it does not possess any nutritional value. A plant may have different type of pectins which varies in structure and chemical composition in different parts of plant as well as at different stages of growth and maturation of fruits [7]. The carbonyl groups in galacturonate units of pectin are $60-90 \%$ esterified with methanol, thus, produces methyl esters and these can be partially or completely neutralized by sodium, potassium or ammonium ions. They are present in the form of calcium pectate and magnesium pectate [8]. Pectin is a water soluble polymer that has at least $75 \%$ esterification [9]. The gel forming properties of pectin depends upon the degree of esterification. High methoxy Pectins contain more than $50 \%$ esterification and low methoxy pectin has less than $50 \%$ esterification. There are other pectin forms reported in various plant tissues such as protopectin and pectinic acid.

\section{Protopectin}

These are water insoluble pectin that is present in intact tissues. More than $90 \%$ of the carbonyl groups in protopectin are esterified with methanol and are cross-linked with calcium ions or other polysaccharides.

\section{Pectinic acid}

In this less than $75 \%$ of galacturonate units are methylated. They are soluble in water and are able to form gel in sugar and acidic medium. The acidic salts of pectinic acids are called pectinates.

\section{Pectic acid}

At least $75 \%$ galacturonate units are methylated in this. These are soluble in water. Pectic acids or their acidic salts are known as pectates.

\section{Pectinases Enzymes}

Pectinases are the heterogeneous group of enzymes that are classified into polygalcturonase $(\mathrm{PG})$, pectinesterase (PE), and pectin lyase (PL) based on their mode of action on the substrate. These enzymes break the pectin polymer into smaller fragments by hydrolysis, trans-elimination and de-esterification reactions, respectively. There are two main enzymes reported, which able to hydrolyze glycosidic linkages. First is polygalacturonase $(\mathrm{PG})$, also Known as pectin depolymerise enzymes. which act on $\alpha 1 \rightarrow 4$ glycosidic bond of the main chain of polygalacturonic acid and hydrolyse it by release of a water molecule. Second is polymethylgalacturonases (PMG) enzymes which catalyze the hydrolytic cleavage of $\alpha(1 \rightarrow 4)$ glycosidic bonds.

Enzymes that involve in de-esterification reaction include pectinesterases (PE), also known as pectin methyl hydrolase. They catalyze de-esterification of the methoxyl group of pectin and yields pectic acid. Enzymes that cleave $\alpha(1 \rightarrow 4)$ glycosidic linkage by transelimination reaction include polymethyl galacturonate lyases (PMGL) and catalyze trans-eliminative cleavage of pectin and produce unsaturated galacturonates [10].

\section{Enzyme Production}

Pectinases are produced by plants as well as by bacteria, yeast and fungus. Many microorganisms are reported to produce pectinase enzyme such as Saccharomyces, Bacillus, Erwinia, Aspergillus, Penicillium, Rhizopus and Fusarium etc. Out of all the microorganisms, fungus is preferred for production of enzymes due to high yield and ability to withstand slight changes in the environment such as temperature, $\mathrm{pH}$ and pressure [11]. Many industrially important products such as enzymes, ethanol, citric acid etc are produced by many filamentous fungi like various species of Aspergillus, Penicillium, Trichoderma, Mucor and many more. Fungi that are Generally Regarded as Safe (GRAS) by United States Food and Drugs Administration (USFDA) are employed in both submerged and solid state fermentation to produce enzymes $[12,13]$.

\section{Uses of pectinase enzyme in fruit juice industries}

Fruit juices are extracted by mechanical grinding of the fruits that result in the jelly like products. Due to complex pectin structure of fruits, it is difficult to extract juice from this highly viscous jellified pulp [14]. Pectinase enzyme acts on the pectin and breaks the glycosidic bonds present between the galacturonic acid monomers thereby decreases the water holding capacity of pectin. Hence high yield of juice is obtained [15]. Many studies have been published which show that the juice yield is increased twice with the treatment of the pectinase enzyme. Different fruit juices need different types of enzyme treatment depending upon the consumer's acceptance for example apples, berries, grapes etc need an intense pectinase treatment along with cellulases for complete clearance of the haze, turbidity and viscosity (Figure 1). On the other hand fruit juice like orange and pineapple etc need only mild pectinase treatment for the extraction of juice and to get high yield of juice but no intense clarification as these juices are consumed by the people, having characteristic pulpy clouds in it. To obtain the desired product, process parameters are needed to be optimised for example like enzyme concentration, enzyme treatment duration, incubation temperature and $\mathrm{pH}$ of solution.

Apple juice processing industries apply pectinase treatment twice during the whole process. During a pre-press treatment, the apple fruit puree is given a pectinase treatment at $30-35^{\circ} \mathrm{C}$ for $30 \mathrm{~min}$ to 2 hours depending upon the type of fruit and incubation temperature. This first enzyme treatment helps in the extraction of juice by breaking the insoluble pectin structure between cells thus release of the liquid what is nothing but the juice [16]. Pectinase treatment results in the flocculation of the pectin and protein complexes which fasten 
up the filtration process. Pectin along with starch complex is responsible for the characteristic viscosity and turbidity of the juice. The pectin-starch and along with protein complexes colloids are present in the juice that have to be removed with enzymatic treatment with pectinase enzyme to reduce the viscosity and turbidity [17]. These colloids are also responsible for the delayed filtration process as well as fouling of the membranes [18]. During the clarification step in apple juice processing, the filtered juice is given a second treatment of pectinase enzyme along with some amylases. Pectinase enzyme removes the soluble pectin from the juice and amylases are used to remove the starch from the juice that causes the unwanted haze in the juice and also is responsible for the gel formation in the juice during storage. Enzymatic processing of fruit juices is done by clearing juice through removal of the turbidity and haze. Pectinase breaks the polysaccharide pectin into small monomers i.e. galacturonic acid that are negatively charged. Thus, the scattering effect of light enhance, which results in the immediate increase in turbidity but decrease in viscosity as well. These negatively charged galacturonic acid monomers attracted by the positively charged proteins to produces complexes structures and due to the electrostatic agglomeration of the oppositely charged particles the turbidity of juice decreased [19]. Pectinase treatment not only improves the juice quality by lowering its viscosity and turbidity but also it improves its colour. Enzyme treatment makes the juice clear and transparent by removing the unwanted haze due to pectin fibers as well as improves the visibility by preventing the darkening of juice and providing the characteristic colour of the juice [20]. All these parameters are very important at commercial level for the easy acceptance by the consumers.

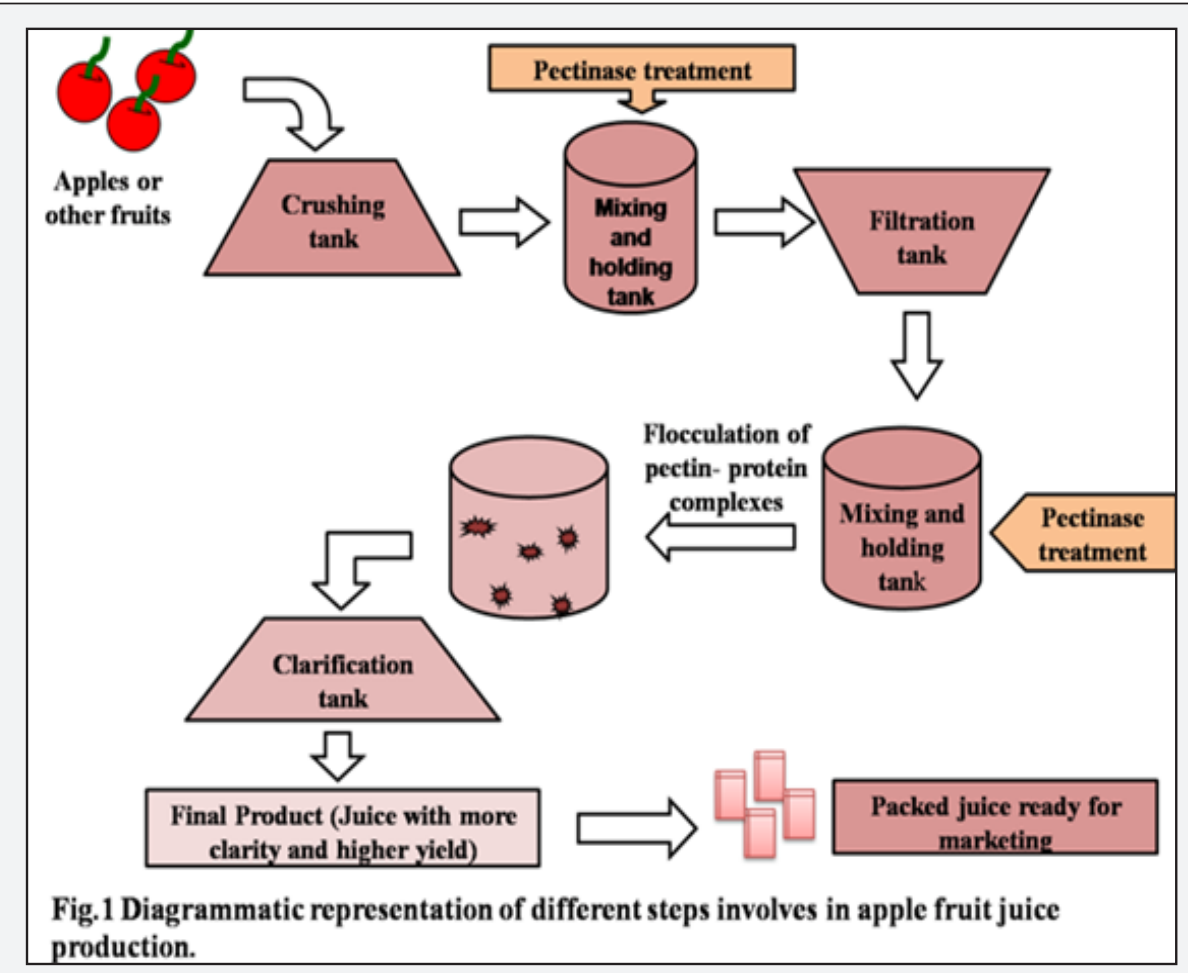

Figure 1: Diagrammatic representation of different steps involves in apple fruit juice.

\section{Conclusion}

Use of enzymes at various stages in fruit processing is a cost effective way to get an improved quality of product i.e. juices. Enzymes are being used for juice clarification, to reduce turbidity, viscosity and astringency in taste, to improve colour and to increase the yield of juice. For the efficient usage of the enzymes it is necessary to optimise the enzyme dose, incubation temperature and the incubation time of enzyme action. To further reduce the overall cost, research Should be conducted in area of immobilisation of pectinase enzyme for reusing purpose.

\section{Future Aspects}

For the improvement of fruit processing, immobilisation of enzymes is being employed that provide the easy process and reduces the overall product cost. By immobilising enzymes, they can be reuse again and again. It makes the easy removal of the enzymes from the juices. As different fruits requires different processing treatments likedifferent enzymes for example cellulases, amylases and pectinases in optimized concentration can be immobilized according to the specific fruit and the optimized process to reduce the enzyme cost and incubation time. New methods can be found and optimized 
to reduce the processing steps and to use the enzymes in a single treatment steps. The overall goal is to make valuable products in a cost effective way that are easily accepted by the consumers and benefit them in their health.

\section{References}

1. Hyson DA (2014) "A Review and critical analysis of the scientific literature related to $100 \%$ fruit juice and human health." Adv Nutr 6(1): 37-51.

2. Tapre AR, Jain RK (2014) "Pectinases: Enzymes for fruit processing industry". International Food Research Journal 21(2): 447-453.

3. Chandrasekaran M, Basheer SM, Chellappan S, Krishna JG, Beena PS (2015) "Enzymes in food and beverage production: an overview," Enzymes in Food and Beverage Processing p. 117

4. Agarwal PK (2006) "Enzymes: An integrated view of structure, dynamics and function." Microb Cell Fact 5(1): 2.

5. Yapo BM, Lerouge P, Thibault JF, Ralet MC (2007) “Pectins from citrus peel cell walls contain homogalacturonans homogenous with respect to molar mass, rhamnogalacturonan I and rhamnogalacturonan II". Carbohydrate Polymers 69: 426-435.

6. Sieiro C, García-Fraga B, López-Seijas J, da Silva AF, Villa TG (2012) “Microbial pectic enzymes in the food and wine industry," In Food industrial processes-Methods and Equipment. InTech.

7. Mohnen D (2008) Pectin structure and biosynthesis. Curr Opin Plant Biol 11(3): 266-277.

8. Kashyap DR, Vohra PK, Chopra S, Tewari R (2001) Applications of pectinases in the commercial sector: a review. Bioresour Technol 77(3): 215-227.

9. Sriamornsak P (2003) Chemistry of pectin and its pharmaceutical uses: A review. Silpakorn University International Journal 3(1-2): 206228.

10. Tapre AR, Jain RK (2001) Pectinases: Enzymes for fruit processing industry. International Food Research Journal 21(2): 447-453.
11. Khairnar Y, Krishna KV, Borast A, Gupta N, Trivedi S, et al. (2009) Study of pectinase production in submerged fermentation using different strains of Aspergillus Niger. International Journal of Microbiology Research 1(2): 13-17.

12. Banakar SP, Thippeswamy B (2012) Isolation, production and partial purification of fungal extracellular pectinolytic enzymes from the forest soils of Bhadra Wildlife Sanctuary, Western Ghats of Southern India. J Biochem Tech 3(5): 138-143.

13. Deshmukh N, Talkal R, Jha K, Singh PG, Prajapati DC (2012) Production, purification, characterization and comparison of polygalacturonase from various strains of aspergillus. International Journal of Scientific \& Technology Research 1(9).

14. Kumar S (2015) Role of enzymes in fruit juice processing and its quality enhancement. Pelagia Research Library Advances in Applied Science Research 6(6): 114-124.

15. Ali A, Williams IH, Martin GB, Sipsas S (2005) Hydrolysis of lupin pectin by pectinases for broilers. Proceedings of the Australian Poultry Science Symposium Conference Paper.

16. Enzymes in Furit Juice Production.

17. Hmid I, Elothmani D, Oukabli A (2016) Effects of enzymatic clarification of pomegranate juice by protease and pectinase treatments. Journal of Bio Innovation 5(4): 506-515.

18. Kumar GP, Suneetha V (2016) Microbial Pectinases: Wonderful enzymes in fruit juice clarification. International Journal of MediPharm Research 2(2): 119-127.

19. Hmid I, Elothmani D, Oukabli A (2016) Effects of enzymatic clarification of pomegranate juice by protease and pectinase treatments. J Bio Innov 5(4): 506-515.

20. Kumar S (2015) Role of enzymes in fruit juice processing and its quality enhancement. Pelagia Research Library Advances in Applied Science Research 6(6): 114-124.

\section{Your next submission with Juniper Publishers} will reach you the below assets

Commons

DOI: 10.19080/NFSIJ.2018.05.555673 